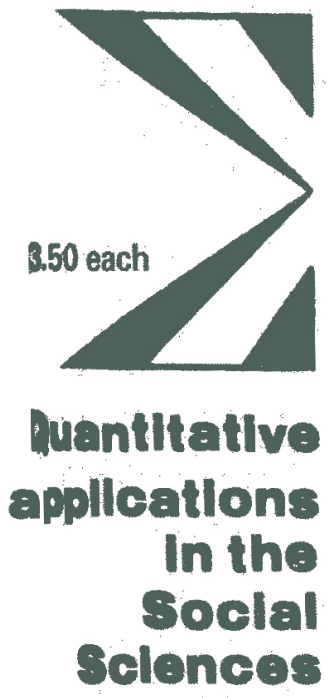

A Sage University

Papers Series

\section{SPECIAL OFFER}

(on prepaid orders only) order 4 or mare for $\$ 3.00$ each OR

Order all 18

for $\$ 49.50$ and save $\$ 13.50$ brief, clearly inticulated uplanations of edvanced methodological concepts good for classroom, professional and library use...

SAGE Publications Beverly Hills London
ORDER CARD

\section{Quantitative Applloations In the Soolal Solonoes \\ A Sage University Papers Series}

\section{NAME}

ADDRESS

CITY

STATE

ZIP

$\square$ I want to take advantage of your Prepaid Special Offer.

$\square$ Please send me all 18 Papers at the prepaid price of $\$ 49.50$.

$\square$ Please send me the Sage Papers checked below (4 or more) at the prepaid discount price of $\$ 3.00$ each.

My check or money order is enclosed.

$\square$ Please send me the Sage Papers checked below at the regular price of $\$ 3.50$ each.

$\square$ ANALYSIS OF VARIANCE Iversen/Norpoth

$\square$ OPERATIONS RESEARCH METHODS Nage//Neef

DCAUSAL MODELING Asher

$\square$ TESTS OF SIGNIFICANCE Henkel

$\square$ COHORT ANALYSIS Glenn

$\square$ CANONICAL ANALYSIS \& FACTOR COMPARISON LEVInE

ANALYSIS OF NOMINAL DATA Reynolds

ANALYSIS OF ORDINAL DATA Hildebrand/Laing/Rosenthal

$\square$ TIME SERIES ANALYSIS: Regression Techniques Ostrom

$\square$ ECOLOGICAL INFERENCE Langbein/Lichtman

$\square$ MULTIDIMENSIONAL SCALING Kruskal Wish

$\square$ ANALYSIS OF COVARIANCE Wildt/Ahtola

$\square$ INTRODUCTION TO FACTOR ANALYSIS $\mathrm{Kim} / \mathrm{Mueller}$

$\square$ FACTOR ANALYSIS $\mathrm{Kim} / \mathrm{MuE} / \mathrm{l}$ r

$\square$ MULTIPLE INDICATORS: An Introduction Suttivan/Feddman

EXPLORATORY DATA ANALYSIS HertwighDearing

$\square$ RELIABILITY \& VALIDITY ASSESSMENT Camines/Zeller

D ANALYZING PANEL DATA Markus

* Orders Under $\$ 10$ MUST be prepaid.

California residents add $6 \%$ sales tax.

All prices subject to change withour notice.

SAGE Publications, Inc.

P. O. Box 5024 Beverly Hilis, Calif. 90210 


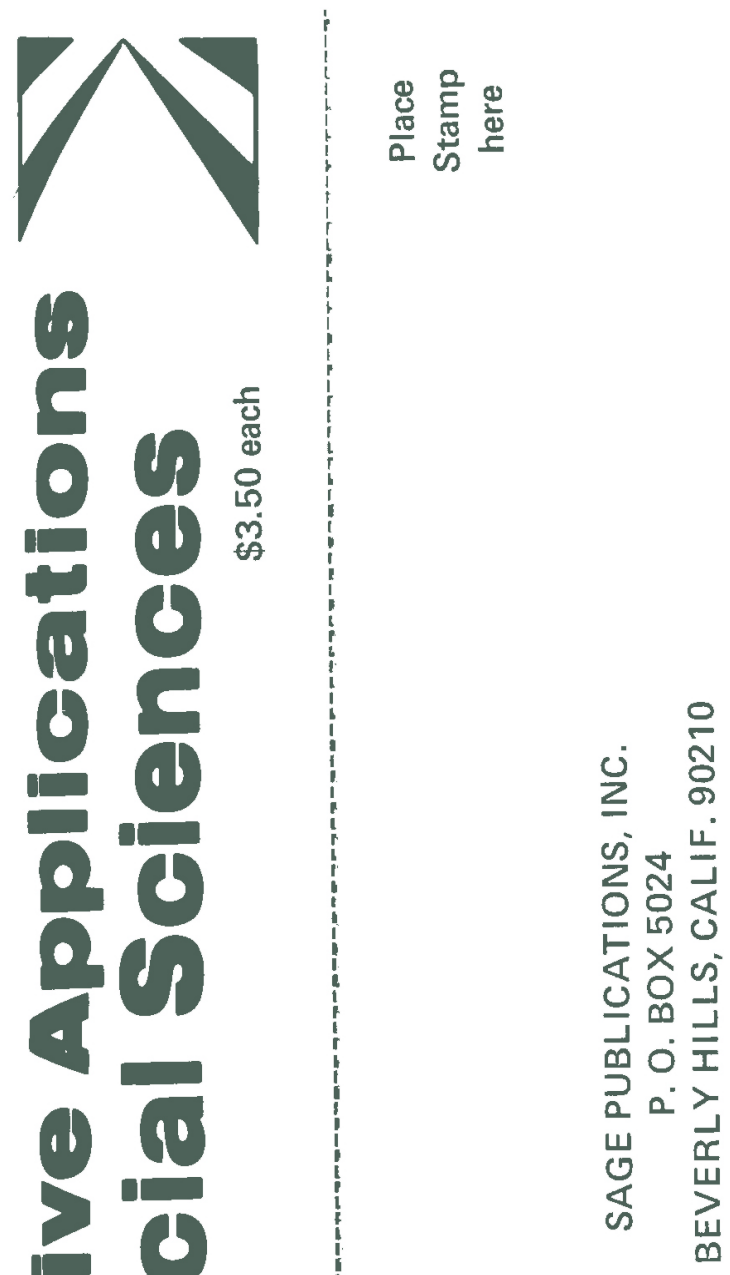




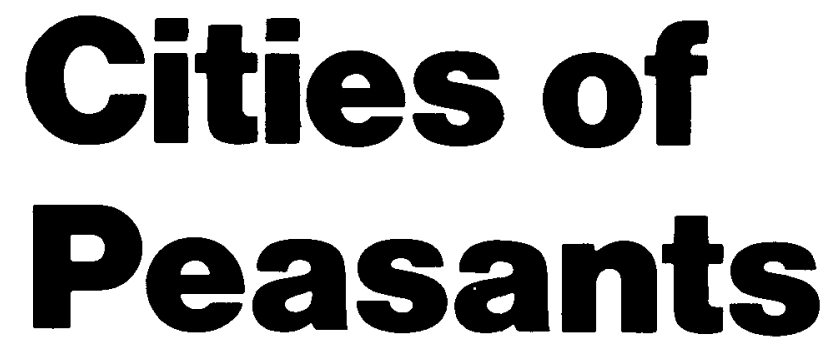

by Bryan Roberts, University of Manchester

Focusing on the most securely capitalist of all underdeveloped regions the continent of Latin America-Roberts traces the growth of urbanbased industrialism and its impact, both externally and internally. He shows how it has transiormed the economy and produced new political and social pressures, the significance of which can be seen in the daily economic activities, social relationships, and even religious behavior of people in Third World cities.

"... It will undoubtedly take its place in the scholarly world as the broadest and best informed overview of the Latin American urbanization process, and will yield important clues for those more generally concerned with political, economic, and social development. The prescontation is lucid and well argued, and the book has the great merit of succunctmess I am glad to see it appear."

- Richard Morse. Stanford University

Explorations in Urban Analysis, Volume 1

1979

ISBN 0-8039-1290-0

216 pages

ISBN 0-8039-1291-9

hardcover
sof tcover

$\$ 18.95$

$\$ 8.95$

SAGE PUBLICATIONS INC 275 South Beveriy Drive Beverly Hills. Californa 90212

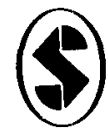

SAGE PUBLICATIONS LTD 28 Banner Street London ECIY 8 QEE. England

Please mention this journal when writing advertisers. 


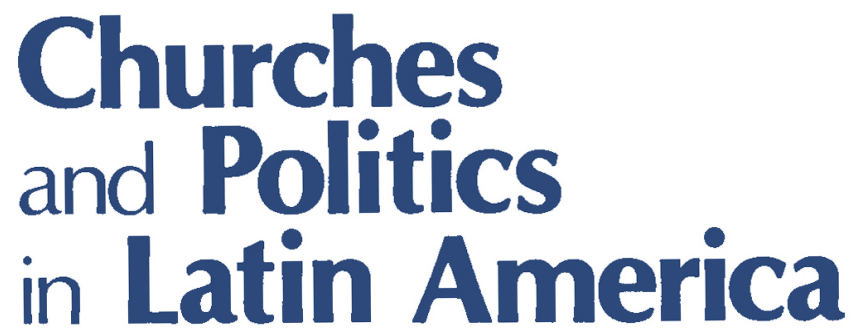

edited by Daniel H. Levine, University of Michigan

Preface by John P. Harrison, University of Miami

The Latin American Church, traditionally an element reinforcing the political status quo, has undergone significant changes in recent years. The contributors to this volume--scholars and clergy from both North and South America-describe these changes and their effects on the relationship between religion and politics in such areas as the Christian left, activist clergy, and the Church and national security

TABLE OF CONTENTS: Preface JOHN P. HARRISON // Part I. Background and General Issues // Introduction / 1. Religion and Politics, Politics and Religion: An Introduction DANIEL H. LEVINE / 2. From Medellin to Puebla: Notes for Reflection RENATO POBLETE, S.J. / 3. What Happened at Puebla PHILLIP BERRYMAN / 4. Latin American Evangelicals: Oaxtepec and Bevond T. S. MONTGOMERY // Part II. Religion and Politics: Points on the Spectrum // Introduction / 5. The Christian Left in Latin American Politics MICHAEL DODSON / 6. The Church and the Doctrine of National Security ROBERT CALVO / 7. Churches and Human Rights in Latin America: Recent Trends on the Subcontinent BRIAN H. SMITH // Part III. Patterns of Innovation // Introduction / 8. Women Religious, the Poor, and the Institutional Church in Chile SISTER KATHERINE ANNE GILFEATHER, M.M. / 9. Basic Christian Communities in Latin America: Their Nature and Significance (especially in Brazil) THOMAS C. BRUNEAU / 10. Salvation Through Chrisı or Marx: Religion in Revolutionary Cuba MARGARET E. CRAHAN / 11. Ten Years of Change in the Church: Puebla and the Future ALEXANDER WILDE / Bibliography

This volume includes some material originally published in the Journal of Interamerican Studies and World Affairs, February 1979.

Sage Focus Editions, Volume 14

1980

ISBN 0-8039-1298-6

288 pages

ISBN 0-8039-1299-4

hardcover

$\$ 18.95$

$\$ 9.95$

SAGE PUBLICATIONS. INC 275 South Beverly Drive

Beverly Hills, Calıforna 90212

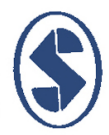

SAGE PUBLICATIONS LTD

28 Banner Street

London ECIY 8OE. England

Please mention this journal when writing advertisers. 